\title{
IMPLEMENTASI BACKTRACKING ALGORITHM UNTUK PENYELESAIAN PERMAINAN SU DOKU POLA 9X9
}

\author{
Febri Utama ${ }^{1)}$, Awang Harsa Kridalaksana ${ }^{2)}$, Indah Fitri Astuti ${ }^{3)}$
}

1,2,3) Jurusan Ilmu Komputer, FMIPA Universitas Mulawarman

Jalan Barong Tongkok No. 4 Kampus Gunung Kelua Samarinda, Kalimantan Timur

Email : febri_shadow@yahoo.co.id ${ }^{1)}$,awangkid@gmail.com²),indahfitriastuti@fmipa.unmul.ac.id ${ }^{3)}$

\begin{abstract}
ABSTRAK
Permainan Su Doku pertama kali muncul pada tahun 1979 di majalah Dell Magazines dengan nama "Number Places", kemudian menjadi populer dengan nama "Su Doku" di Jepang pada tahun 1984. Pada umumnya permainan ini terdiri dari 81 kotak kecil (sel), yang disebut juga dengan Su Doku pola 9x9. Su Doku ini dibagi menjadi 9 grid dengan pola 3x3. Diantara sel-sel tersebut terdapat angka 1 sampai dengan 9 sebagai angka awal. Angka-angka awal ini digunakan sebagai pembatas, sehingga kita hanya melanjutkan dengan mengisi angka hingga seluruh sel-sel terisi penuh masing-masing dengan angka 1 sampai dengan 9. Metode umum pencarian solusi Su Doku adalah dengan kombinasi teknik pemindaian (scanning), penandaan (marking), dan analisa (analyzing). Tujuan penelitian ini adalah untuk membuat suatu aplikasi yang merupakan implementasi dari metode backtracking algorithm untuk menampilkan solusi Su Doku pola 9x9 yang unik dan membuktikan teori ketepatan metode backtracking algorithm dalam penggunaan pencarian solusi $S u$ Doku pola 9x9. Implementasi dari metode backtracking algorithm dibuat dengan bahasa pemrograman Delphi. Hasil penelitian ini adalah sebuah aplikasi pencarian solusi $S u$ Doku dengan pola 9x9, yang diberi nama "Program Aplikasi Sudoku Solver Backtracking Algorithm". Didalam aplikasi ini user menginputkan angka awal sesuai dengan level Su Doku, dimana hasil outputnya adalah tampilan dari solusi unik Su Doku.
\end{abstract}

Kata kunci : Su Doku pola 9x9, backtracking algorithm, sel, angka awal, solusi unik.

\section{PENDAHULUAN}

Permainan $S u$ Doku pertama kali muncul pada tahun 1979 di majalah Dell Magazines dengan nama "Number Places", kemudian menjadi populer dengan nama Su Doku di Jepang pada tahun 1984. Pada umumnya permainan ini terdiri dari 81 kotak kecil (sel), yang disebut juga dengan Su Doku pola 9x9. Su Doku ini dibagi menjadi 9 grid dengan pola $3 \times 3$. Di antara sel-sel tersebut terdapat angka 1 sampai dengan 9 sebagai angka awal. Angka-angka awal ini digunakan sebagai pembatas, sehingga pengguna hanya melanjutkan dengan mengisi angka hingga seluruh sel-sel terisi penuh dengan angka 1 sampai dengan 9 .

Tidak seperti permainan teka-teki silang, yang membutuhkan pengetahuan umum untuk menjawab setiap soal yang ada dan menguasai bahasa tertentu (karena tentunya terdapat istilah asing yang merupakan jawaban dari pertanyaan teka-teki silang tersebut), pengguna tidak perlu memiliki kemampuan pengetahuan umum dan bahasa tertentu untuk dapat menikmati permainan Su Doku. Bahkan secara teknis, pengguna tidak perlu tahu cara berhitung. Pengguna hanya harus menempatkan angka 1 sampai dengan 9, tidak perlu urut kedalam setiap baris (kiri ke kanan), setiap kolom (atas ke bawah), dan setiap grid (yang masing-masing berisi sembilan kotak kecil atau sel). Strategi yang baik adalah dengan mula-mula berpikir dalam grid-grid, atau lebih baik sekumpulan grid, kemudian mencari pasangan angka, yang dari keduanya pengguna dapat menemukan yang ketiga.

Namun, walaupun tidak perlu pengetahuan umum, kemampuan bahasa tertentu dan kemampuan berhitung, tidak mudah menyelesaikan Su Doku. Tantangannya adalah, bagaimana caranya mengisi seluruh sel yang tadinya hanya terdiri dari beberapa angka saja menjadi penuh terisi semua, dengan syarat dari kesembilan angka tersebut tidak boleh terulang disetiap 1 baris, kolom dan gridnya. Boleh dikatakan bila pengguna salah mengisi angka di awal-awal permainan, dapat dengan mudah ditebak pengguna akan mengacaukan aturan permainan dengan kebingungan sendiri, mengapa ada angka yang sama terulang pada baris, kolom atau grid yang sama? (misalnya dalam 1 kolom terdapat dua angka 6 atau dalam satu grid terdapat dua angka 9) yang berakibat pada tidak akan tercapainya solusi akhir dan harus mengulang dari awal.

Untuk mencapai solusi akhir, dibutuhkan sebuah metode yang harus memenuhi persyaratan unik $S u$ Doku, dengan menebak sebuah angka dan mencocokkan angka tersebut dengan keadaan sekelilingnya (dalam hal ini adalah baris, kolom dan grid). Jika terdapat angka yang sama, metode tersebut harus bisa mengganti angka yang sama tersebut dengan angka yang lain, sehingga akan mencapai solusi akhir, yakni sel $\mathrm{Su}$ Doku telah terisi semua dengan angka 1 sampai dengan 9, dengan tidak ada kesamaan angka pada satu baris, 
kolom, dan gridnya. Metode yang cukup efektif dengan persyaratan $\mathrm{Su}$ Doku ini adalah dengan menggunakan metode backtracking algorithm (algoritma runut-balik). Mengapa menggunakan algoritma runut-balik, algoritma runut-balik berbasis pencarian depth first search (pencarian pertama terdalam) merupakan algoritma yang digunakan karena sifatnya yang hanya memberikan satu solusi saja, cukup efektif dengan solusi unik $S u$ Doku yaitu hanya memiliki satu solusi (Arifiyanto, 2007).

\section{LANDASAN TEORI}

\section{Backtracking Algorithm}

Backtracking Algorithm (algoritma runutbalik) adalah sebuah algoritma pencarian yang berdasarkan pada proses pencarian DFS (Depth First Search). Pencarian dengan metode ini dilakukan dari node awal secara mendalam hingga yang paling akhir (dead-end) atau sampai ditemukan. Dengan kata lain, simpul cabang atau anak yang terlebih dahulu dikunjungi (Desiani, 2006).

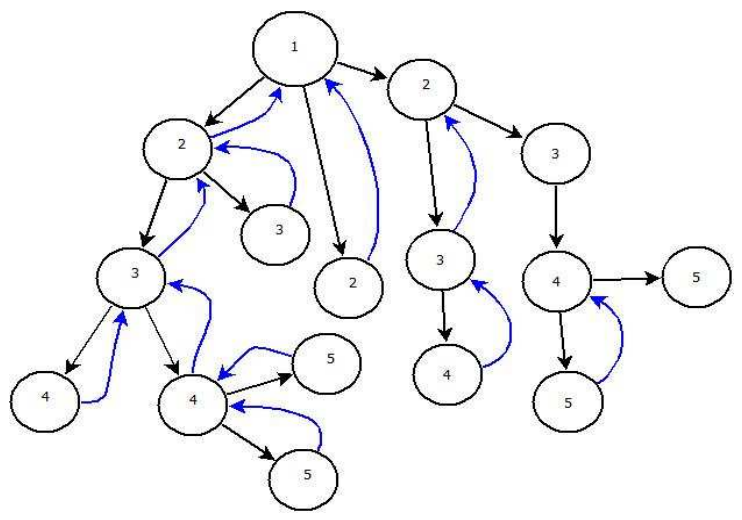

Gambar 1. Teknik pencarian dengan metode backtracking algorithm

Berdasarkan gambar 1, proses pencarian dilakukan dengan mengunjungi cabang terlebih dahulu hingga tiba di simpul terakhir. Jika tujuan yang diinginkan belum tercapai maka pencarian dilanjutkan ke cabang sebelumnya, turun ke bawah jika memang masih ada cabangnya. Begitu seterusnya hingga diperoleh tujuan akhirnya (Goal). Dengan metode backtracking ini, dalam proses pencariannya tidak mengarah kepada semua kemungkinan solusi yang ada, hanya mengarah kepada satu solusi saja. Akibatnya rentang waktu dalam pencarian solusi lebih sedikit (proses pencarian menjadi lebih efektif dan efisien). Bactracking algorithm lebih alami dinyatakan dalam recursif algorithm (algoritma rekursif). Kadang-kadang algoritma ini (backtracking algorithm) disebut pula sebagai bentuk tipikal dari algoritma rekursif (recursif algorithm).

\section{Su Doku}

Nikoli, sebuah penerbit di Jepang, menyatakan Su Doku sebenarnya penyederhanaan kalimat bahasa Jepang "Suuji wa dokushin ni kagiru," yang berarti "terbatas hanya angka tunggal", sedangkan Su berarti angka dan Doku berarti tunggal. Nikoli pertama kali melihatnya di majalah Amerika, Dell Puzzle Magazines, yang disebut dengan "Number Place." Puzzle Number Place ini adalah hasil karya seorang arsitek, Howard Garns di tahun 1979, terinspirasi oleh Latin Squares, sebuah konsep matematika temuan Leonard Eulers, warga Swiss pada tahun 1783. Sejak tahun 1984 Nikoli menerbitkan Su Doku (Musadik, 2010).

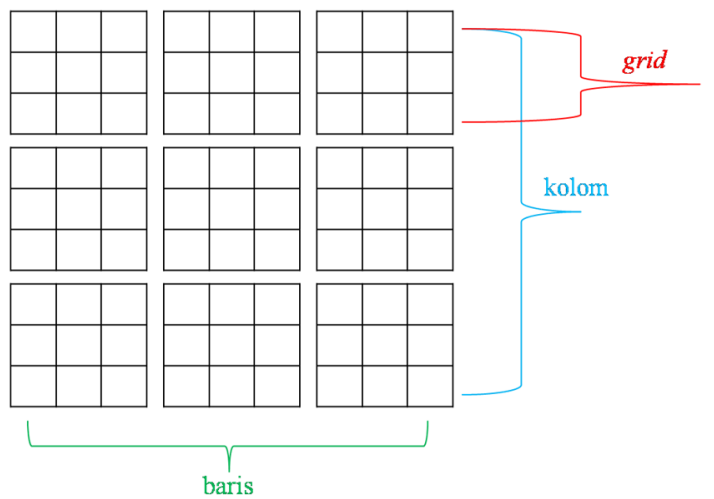

Gambar 2. Ilustrasi pembagian sel

\begin{tabular}{|l|l|l|l|l|l|l|l|l|}
\hline 6 & & & & 5 & 8 & 4 & 9 & \\
\hline & 2 & 4 & & & & & & \\
\hline & & & & 2 & & & 3 & 6 \\
\hline & & & & & & 9 & & 7 \\
\hline 7 & & & 3 & & & 8 & & \\
\hline 1 & 5 & & & 8 & 9 & & & \\
\hline & 3 & 1 & & & & & & \\
\hline & & & & 3 & & 5 & & \\
\hline & & 8 & & 9 & 5 & & & \\
\hline
\end{tabular}

Gambar 3. Su Doku terdiri dari 9 baris dan kolom dan dibagi lagi menjadi 9 grid

Pada umumnya, permainan $S u$ Doku ini terdiri dari 9 buah kolom dan baris, dan dipisahkan lagi menjadi 9 kotak berukuran $3 \times 3$ yang selanjutnya disebut dengan grid. Dari gambar 2.2 terlihat bahwa hasil solusi dari permainan $\mathrm{Su}$ Doku ini adalah untuk setiap kotak kecil (sel) dan setiap grid-nya terdiri dari angka 1 sampai dengan angka 9, dimana tidak boleh ada angka yang terulang disetiap 1 baris, kolom, dan grid-nya. Sehingga dapat disimpulkan pada permainan $\mathrm{Su}$ Doku ini penyelesaiannya terdiri dari pola yang unik dan hanya terdapat satu solusi saja. 


\begin{tabular}{|l|l|l|l|l|l|l|l|l|}
\hline 6 & 7 & 3 & 1 & 5 & 8 & 4 & 9 & 2 \\
\hline 9 & 2 & 4 & 6 & 7 & 3 & 1 & 5 & 8 \\
\hline 8 & 1 & 5 & 9 & 2 & 4 & 7 & 3 & 6 \\
\hline 3 & 8 & 6 & 5 & 4 & 2 & 9 & 1 & 7 \\
\hline 7 & 4 & 9 & 3 & 1 & 6 & 8 & 2 & 5 \\
\hline 1 & 5 & 2 & 7 & 8 & 9 & 6 & 4 & 3 \\
\hline 5 & 3 & 1 & 4 & 6 & 7 & 2 & 8 & 9 \\
\hline 2 & 9 & 7 & 8 & 3 & 1 & 5 & 6 & 4 \\
\hline 4 & 6 & 8 & 2 & 9 & 5 & 3 & 7 & 1 \\
\hline
\end{tabular}

Gambar 4. Solusi akhir Su Doku

\section{Strategi Umum Penyelesaian Su Doku}

Secara umum, Su Doku dapat diselesaikan dengan kombinasi teknik pemindaian (scanning), penandaan (marking), dan analisa (analyzing) (Morenvino, 2006).

1. Pemindaian, berupa proses memindai baris atau kolom untuk mengindentifikasi baris mana dalam suatu grid yang terdapat angka-angka tertentu. Proses ini kemudian diulang pada setiap kolom (atau baris) secara sistematis. Kemudian menentukan nilai dari suatu sel dengan membuang nilai-nilai yang tidak mungkin.

2. Penandaan, berupa analisa logika dengan menandai kandidat angka yang dapat dimasukkan dalam sebuah sel.

3. Analisa, berupa eliminasi kandidat, dimana kemajuan dicapai dengan mengeliminasi kandidat angka secara berturut-turut hingga sebuah sel hanya punya 1 kandidat.

\section{METODE PENELITIAN}

Penelitian ini pada intinya adalah untuk menghasilkan aplikasi yang mampu menyelesaikan masalah penyelesaian permainan $S u$ Doku pola 9x9, dengan tahap :

1. Solusi dicari dengan membentuk lintasan dari akar ke daun. Aturan pembentukan yang dipakai adalah mengikuti aturan pencarian mendalam (DFS). Simpul-simpul yang sudah dilahirkan dinamakan simpul hidup (live node). Simpul hidup yang sedang diperluas dinamakan simpul-E (Expand-node).

2. Tiap kali simpul-E diperluas, lintasan yang dibangun olehnya bertambah panjang. Jika lintasan yang sedang dibentuk tidak mengarah ke solusi, maka simpul-E tersebut "dibunuh" sehingga menjadi simpul mati (dead node). Fungsi yang digunakan untuk membunuh simpul-E adalah dengan menerapkan fungsi pembatas (bounding function). Simpul yang sudah mati tidak akan pernah diperluas lagi.

3. Jika pembentukan lintasan berakhir dengan simpul mati, maka proses pencarian diteruskan dengan membangkitkan simpul anak yang lainnya. Bila tidak ada lagi simpul anak yang dapat dibangkitkan, maka pencarian solusi dilanjutkan dengan melakukan runut-balik ke simpul hidup terdekat (simpul orangtua). Selanjutnya simpul ini menjadi simpul-E yang baru.

4. Pencarian dihentikan bila kita telah menemukan solusi atau tidak ada lagi simpul hidup untuk runut-balik.

\section{HASIL DAN PEMBAHASAN Implementasi User Interface}

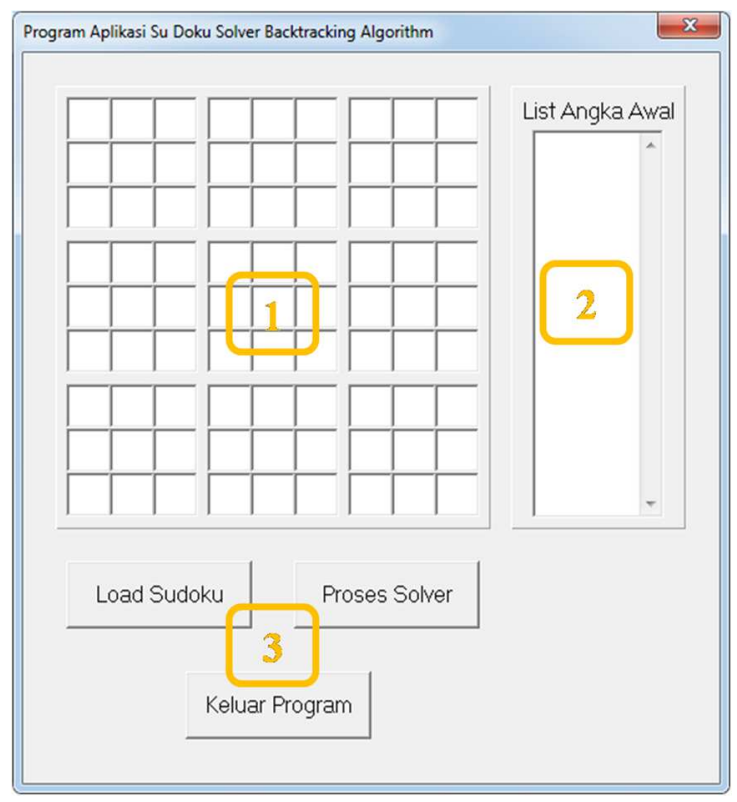

Gambar 5. User interface aplikasi

User interface aplikasi terdiri dari tiga bagian, yaitu :

1. Matriks Su Doku ( berisi angka awal dan angka solusi).

2. List angka awal yang berfungsi sebagai inisiasi angka awal dari file berekstensi*.txt (file notepad) kedalam sistem matriks $[9,9]$ dalam program.

3. Tombol eksekusi perintah (memilih level $\mathrm{Su}$ Doku, proses pencarian solusi Su Doku, dan keluar dari aplikasi Su Doku Solver).

\section{Implementasi Backtracking Algorithm}

Penerapan backtracking algorithm dalam solusi Su Doku adalah :

1. Sistem memulai algoritma dari sel kosong yang pertama pada matriks.

2. Proses pencarian solusi secara umum dimulai berurutan dari sel kiri atas (a11) menuju ke sel kanan bawah (a99). 


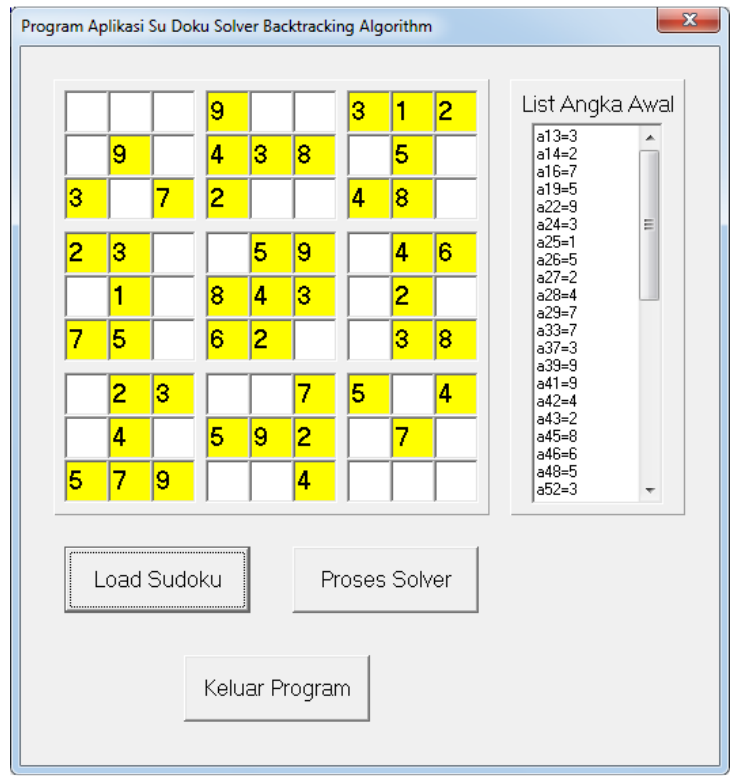

Gambar 6. Tampilan angka awal pada matriks $S u$ Doku dan list angka awal

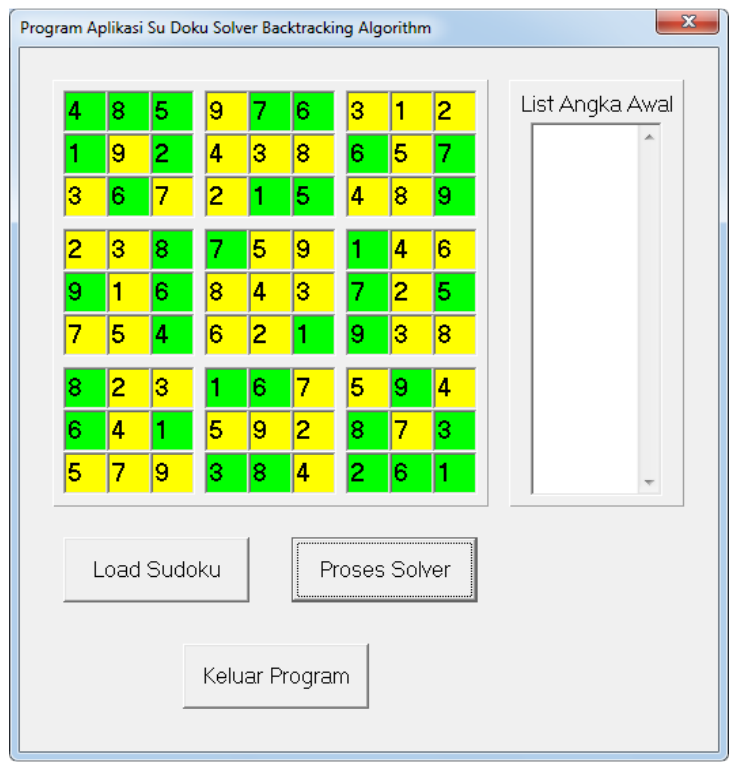

Gambar 7. Tampilan solusi akhir Su Doku

3. Proses pencarian pada baris dimulai berurutan dari sel kiri menuju ke sel kanan, pencarian pada kolom dimulai berurutan dari sel atas ke sel bawah, dan pencarian pada grid dimulai berurutan dari sebelah kiri atas ke sebelah kanan bawah.

4. Kumpulkan seluruh angka-angka yang menjadi kemungkinan solusi yaitu angka kemungkinan solusi, yang terdiri dari angka 1 sampai dengan 9, dan menempatkan kemungkinan solusi tersebut kedalam sistem data array.

5. Jika pada satu sel kosong terdapat lebih dari satu kemungkinan solusi, aplikasi menggunakan kemungkinan solusi dengan nilai terkecil untuk mengisi sel kosong tersebut.

6. Lakukan proses pengecekan apakah angka kemungkinan solusi memenuhi fungsi pembatas atau tidak. Fungsi pembatas yaitu tidak boleh ada angka yang sama pada satu baris, satu kolom, dan satu grid, serta tidak mengubah angka awal.

a. Jika memenuhi fungsi pembatas, maka sel kosong tersebut diisi dengan angka kemungkinan solusi, kemudian proses pengecekan dilanjutkan ke sel kosong berikutnya.

b. Jika tidak memenuhi fungsi pembatas, maka angka kemungkinan solusi diganti dengan angka kemungkinan solusi berikutnya yang belum dipakai.

7. Apabila seluruh angka kemungkinan solusi telah diganti dan masih belum memenuhi fungsi pembatas, maka lakukan proses backtracking ke sel sebelumnya. Sel sebelumnya ini merupakan sel yang telah terisi dengan kemungkinan solusi, bukan yang terisi dengan angka awal.

8. Pada sel dari hasil proses backtracking ini, jika terdapat lebih dari satu angka kemungkinan solusi, angka solusi yang lama diganti dengan angka kemungkinan solusi yang berkutnya, kemudian dilakukan pengecekan kembali apakah memenuhi fungsi pembatas atau tidak.

a. Jika memenuhi fungsi pembatas, maka sel akan diisi dengan angka kemungkinan solusi yang baru dan menjadi angka solusi yang baru, serta menghapus angka kemungkinan solusi yang lama. Kemudian proses pengisian sel kosong dengan kemungkinan solusi dilanjutkan ke sel berikutnya.

b. Jika seluruh angka kemungkinan solusi yang baru tidak memenuhi fungsi pembatas, maka lakukan proses backtracking ke sel sebelumnya.

9. Aplikasi akan melakukan semua proses terusmenerus (proses 1 sampai proses 8) hingga ditemukan solusi yang valid atau tidak ditemukan solusi yang valid.

a. Solusi dinyatakan valid jika aplikasi berhasil mengisi semua sel kosong yang tersedia dengan angka solusi yang memenuhi fungsi pembatas.

b. Solusi dinyatakan tidak valid jika dalam proses pencarian angka solusi, aplikasi melakukan backtracking hingga kembali ke sel kosong yang pertama (a11) dan tidak menemukan angka solusi untuk mengisi sel kosong.

\section{Implementasi Pengisian Angka Pada Aplikasi}

Dari gambar 6, jika seluruh sel kosong diisi dengan kemungkinan solusi dimana tidak memiliki kesamaan angka pada satu baris, kolom, dan grid, dengan angka awal yang telah diberi warna kuning pada selnya, maka hasilnya dapat dilihat pada gambar 8 . 


\begin{tabular}{|c|c|c|c|c|c|c|c|c|}
\hline $4,6,8$ & $4,6,8$ & $4,5,6,8$ & 9 & 6,7 & 5,6 & 3 & 1 & 2 \\
\hline 1,6 & 9 & $1,2,6$ & 4 & 3 & 8 & 6,7 & 5 & 7 \\
\hline 3 & 6 & 7 & 2 & 1,6 & 5,6 & 4 & 8 & 9 \\
\hline 2 & 3 & 8 & 1,7 & 5 & 9 & 1,7 & 4 & 6 \\
\hline 6,9 & 1 & 6 & 8 & 4 & 3 & 7,9 & 2 & 5,9 \\
\hline 7 & 5 & 4 & 6 & 2 & 1 & 1,9 & 3 & 8 \\
\hline $1,6,8$ & 2 & 3 & 1 & $1,6,8$ & 7 & 5 & 6,9 & 4 \\
\hline $1,6,8$ & 4 & $1,6,8$ & 5 & 9 & 2 & $1,6,8$ & 7 & 1,3 \\
\hline 5 & 7 & 9 & 1,3 & $1,6,8$ & 4 & $1,2,6,8$ & 6 & 1,3 \\
\hline
\end{tabular}

Gambar 8. Tampilan seluruh sel kosong terisi dengan kemungkinan solusi

\begin{tabular}{|l|l|l|l|l|l|l|l|l|}
\hline a11 & a21 & a31 & a41 & a51 & a61 & a71 & a81 & a91 \\
\hline a12 & a22 & a32 & a42 & a52 & a62 & a72 & a82 & a92 \\
\hline a13 & a23 & a33 & a43 & a53 & a63 & a73 & a83 & a93 \\
\hline a14 & a24 & a34 & a44 & a54 & a64 & a74 & a84 & a94 \\
\hline a15 & a25 & a35 & a45 & a55 & a65 & a75 & a85 & a95 \\
\hline a16 & a26 & a36 & a46 & a56 & a66 & a76 & a86 & a96 \\
\hline a17 & a27 & a37 & a47 & a57 & a67 & a77 & a87 & a97 \\
\hline a18 & a28 & a38 & a48 & a58 & a68 & a78 & a88 & a98 \\
\hline a19 & a29 & a39 & a49 & a59 & a69 & a79 & a89 & a99 \\
\hline
\end{tabular}

Gambar 9. Ilustrasi permodelan sel kedalam matriks pada $\mathrm{Su}$ Doku

Proses pertama yang dieksekusi oleh aplikasi Su Doku solver adalah memeriksa apakah terdapat sel kosong, jika terdapat sel kosong maka sel kosong tersebut akan menjalani proses kedua yaitu mencari seluruh kemungkinan solusi yang akan mengisi sel kosong tersebut. Pada gambar 7 (a) sel pertama a11 merupakan sel kosong, maka proses pencarian dimulai dari sel a11. Setelah mencari seluruh kemungkinan solusi dengan tidak ada kesamaan angka pada baris, kolom dan grid, maka didapat 3 nilai kemungkinan solusi yaitu 4, 6, dan 8. Kemudian aplikasi akan menggunakan kemungkinan solusi dengan nilai terendah yaitu 4 , untuk mengisi sel a11.

Setelah mengisi sel a11 dengan angka 4, kemudian aplikasi akan melanjutkan pemeriksaan sel kosong ke sel berikutnya yaitu sel a21. Karena sel a21 merupakan sel kosong, maka proses pencarian kemungkinan solusi dieksekusi pada sel a21. Pada sel a21 didapat 2 kemungkinan solusi yaitu 6 dan 8 . Angka 4 tidak termasuk kedalam kemungkinan solusi karena terdapat angka 4 pada sel sebelumnya yaitu a11. Aplikasi menggunakan kemungkinan solusi dengan nilai terendah yaitu 6 , dan menghapus kemungkinan solusi terendah yaitu 4, kemudian mengisi sel a21 dengan angka 6 . Kemudian aplikasi memeriksa sel berikutnya yaitu sel a31. Sel a31 merupakan sel kosong maka proses pencarian kemungkinan solusi dieksekusi pada sel a31. Setelah dilakukan pencarian maka terdapat 2 kemungkinan solusi yaitu 5 dan 8, aplikasi mengisi sel a31 menggunakan kemungkinan solusi dengan nilai terendah yaitu 5 .

Kemudian aplikasi akan memeriksa sel berikutnya yaitu sel a41. Sel a41 bukan merupakan sel kosong, maka proses dilanjutkan ke sel berikutnya yaitu sel a51. Sel a51 merupakan sel kosong, maka proses pencarian kemungkinan solusi dieksekusi pada sel a51. Setelah dilakukan pencarian maka terdapat 1 kemungkinan solusi yaitu 7, aplikasi mengisi sel a51 dengan angka 7 . Kemudian aplikasi memeriksa sel berikutnya yaitu sel a61. Sel a61 merupakan sel kosong maka proses pencarian kemungkinan solusi dieksekusi pada sel a61. Setelah dilakukan ternyata tidak terdapat kemungkinan solusi, maka dilakukan backtracking ke sel sebelumnya yaitu sel a51. Pada sel a51 hanya terdapat 1 kemungkinan solusi, yang hal ini tidak mungkin mengubah kemungkinan solusi tersebut maka isi sel a51 dihapus dan dilakukan kembali proses backtracking kesel sebelumnya yaitu sel a41. Karena sel a41 merupakan angka awal yang tidak boleh diubah nilainya maka, dilakukan kembali backtracking ke sel sebelumnya yaitu a31 dengan tidak menghapus isi dari sel a41.

Pada sel a31 masih tersisa kemungkinan solusi yaitu angka 8 , maka aplikasi mengisi sel a31 dengan angka 8. Kemudian aplikasi melanjutkan pemeriksaan kembali pada sel berikutnya yaitu sel a41. Proses pemeriksaan sel kosong, pencarian kemungkinan solusi, proses pengecekan kesamaan angka pada baris, kolom, grid, dan proses backtracking akan dilakukan terus-menerus hingga seluruh sel kosong terisi dengan angka yang unik, yaitu terdiri dari angka 1 sampai dengan angka 9 yang tidak memiliki kesamaan pada satu baris, kolom, dan gridnya.

Pada gambar 10(a) - (i), proses pencarian solusi dimulai dari sel kiri atas yaitu sel a11 menuju sel kanan bawah yaitu sel a99. Kemungkinan solusi pada sel kosong disimpan didalam sistem data array, kemudian setelah semua sel kosong tersebut telah terisi dengan angka solusi dan tidak ada kesamaan angka pada baris, kolom, dan grid, solusi akhir baru ditampilkan, hal ini untuk mengoptimalkan kecepatan proses pencarian solusi dengan backtracking algorithm. Untuk sel yang terjadi proses backtracking, digunakan warna merah sebagai penanda. Untuk sel yang mengalami perubahan angka kemungkinan solusi, yaitu angka kemungkinan solusi yang lama diganti dengan angka kemungkinan solusi yang baru, digunakan warna biru sebagai penanda. Sedangkan warna merah muda digunakan sebagai sel awal pencarian hasil proses backtracking. Pada gambar 10 (a) - (h), terjadi proses backtracking sebanyak 8 kali. Setelah semua sel kosong telah terisi dengan angka kemungkinan solusi, tidak memiliki kesamaan angka pada baris, kolom, dan grid (gambar 10 (i)), maka angka kemungkinan solusi menjadi solusi akhir yang kemudian akan ditampilkan dengan sel berwarna hijau (gambar $10(\mathrm{j})$ ). 


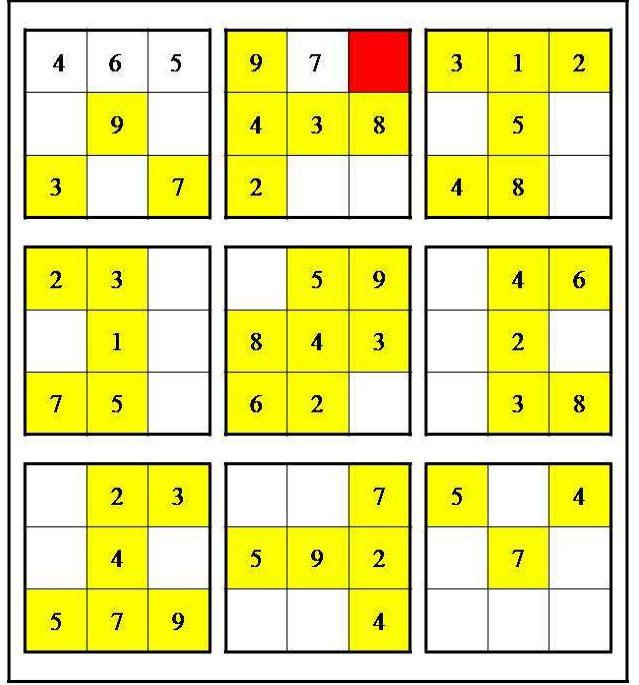

(a)

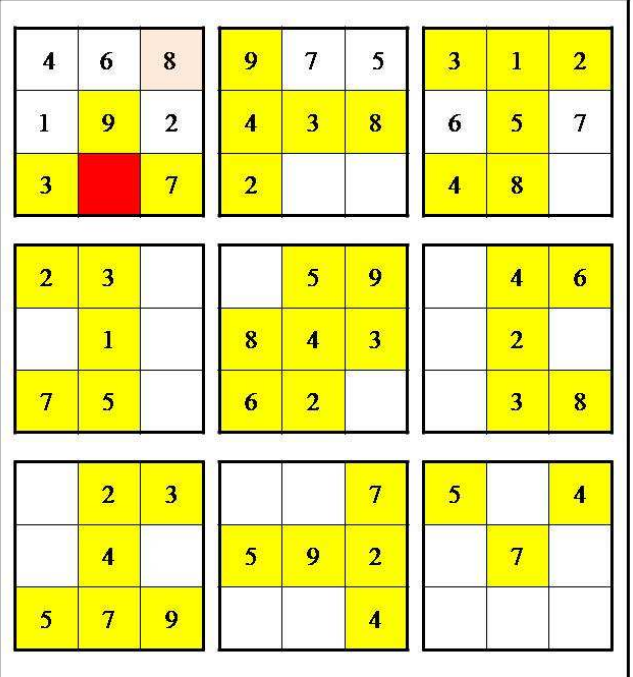

(b)

\begin{tabular}{|c|c|c|c|c|c|c|c|c|}
\hline 4 & 6 & 8 & 9 & 7 & 5 & 3 & 1 & 2 \\
\hline 1 & 9 & 2 & 4 & 3 & 8 & 7 & 5 & \\
\hline 3 & & 7 & 2 & & & 4 & 8 & \\
\hline \multirow[t]{2}{*}{2} & 3 & & & 5 & 9 & & 4 & 6 \\
\hline & 1 & & 8 & 4 & 3 & & 2 & \\
\hline \multirow[t]{3}{*}{7} & 5 & & 6 & 2 & & & 3 & 8 \\
\hline & 2 & 3 & & & 7 & 5 & & 4 \\
\hline & 4 & & 5 & 9 & 2 & & 7 & \\
\hline 5 & 7 & 9 & & & 4 & & & \\
\hline
\end{tabular}

(c)

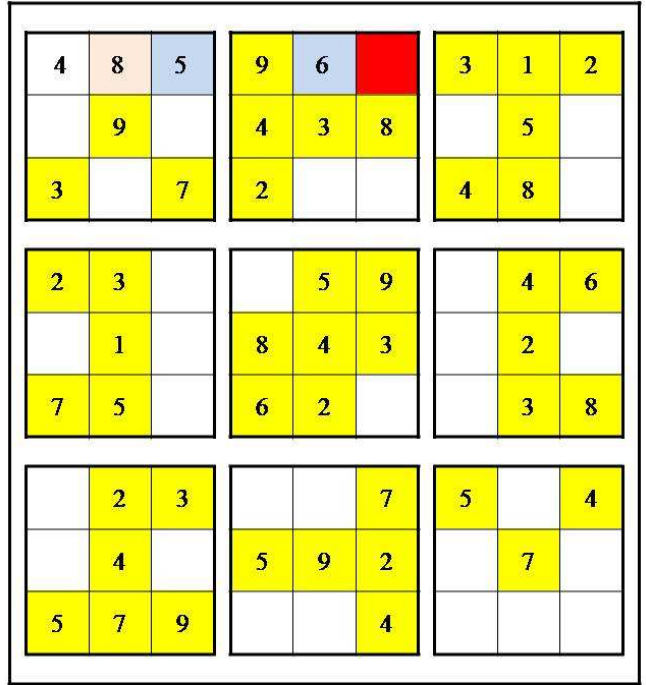

(d)

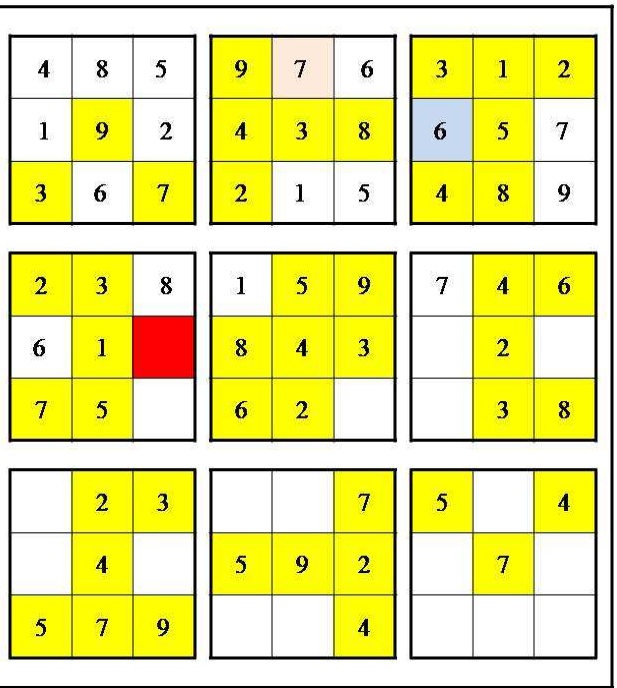

(e)

\begin{tabular}{|c|c|c|c|c|c|c|c|c|}
\hline 4 & 8 & 5 & 9 & 7 & 6 & 3 & 1 & 2 \\
\hline 1 & 9 & 2 & 4 & 3 & 8 & 6 & 5 & 7 \\
\hline 3 & 6 & 7 & 2 & 1 & 5 & 4 & 8 & 9 \\
\hline 2 & 3 & 8 & 1 & 5 & 9 & 7 & 4 & 6 \\
\hline 9 & 1 & 6 & 8 & 4 & 3 & & 2 & \\
\hline 7 & 5 & & 6 & 2 & & & 3 & 8 \\
\hline & 2 & 3 & & & 7 & 5 & & 4 \\
\hline & 4 & & 5 & 9 & 2 & & 7 & \\
\hline 5 & 7 & 9 & & & 4 & & & \\
\hline
\end{tabular}
(f) 


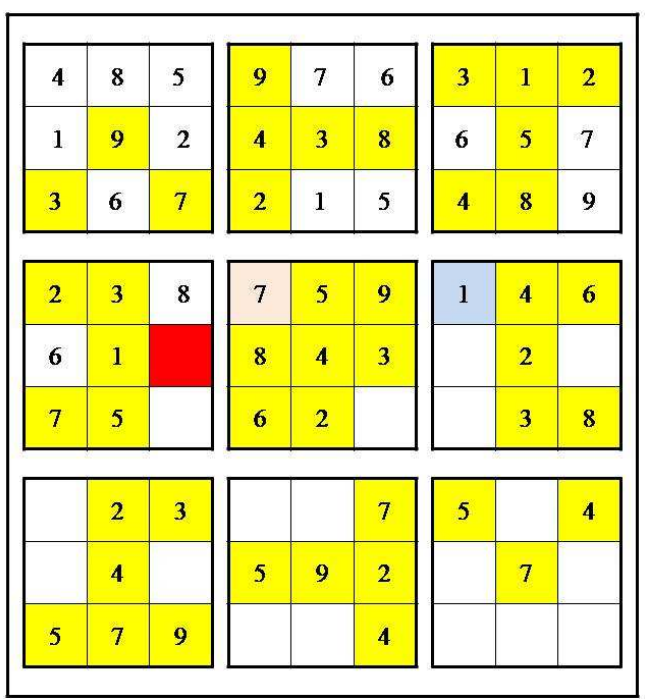

(g)

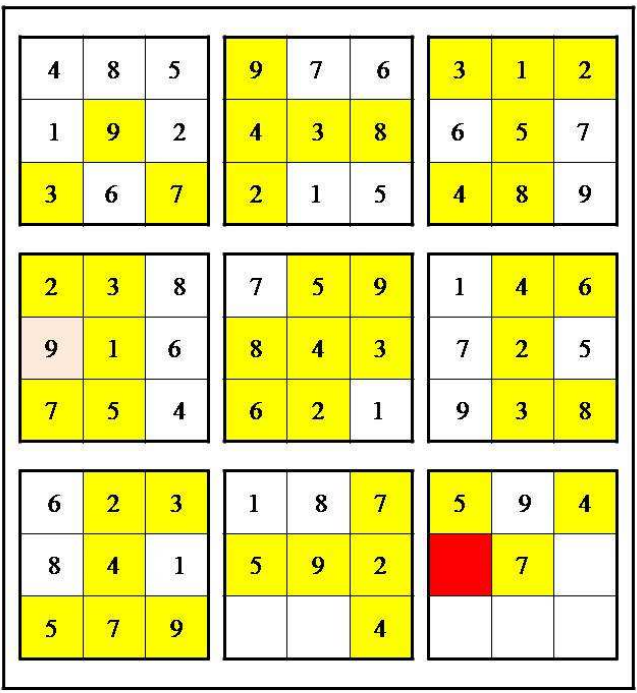

(h)

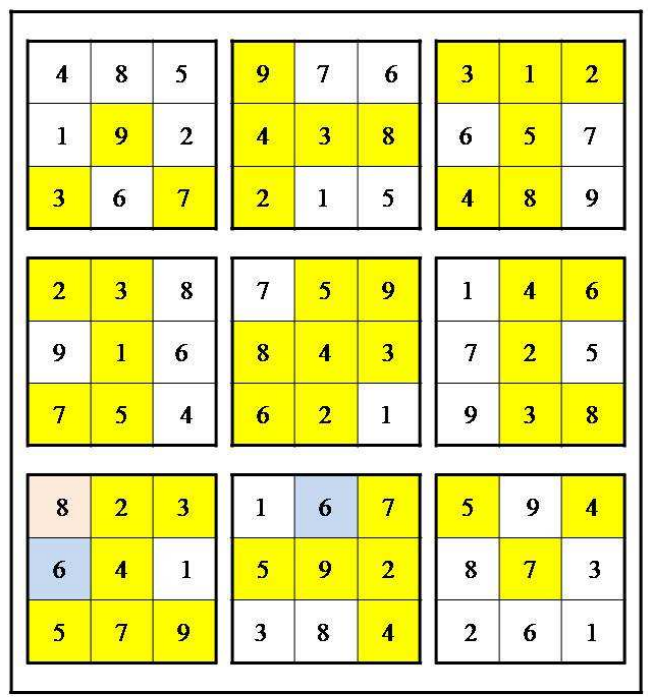

(i)

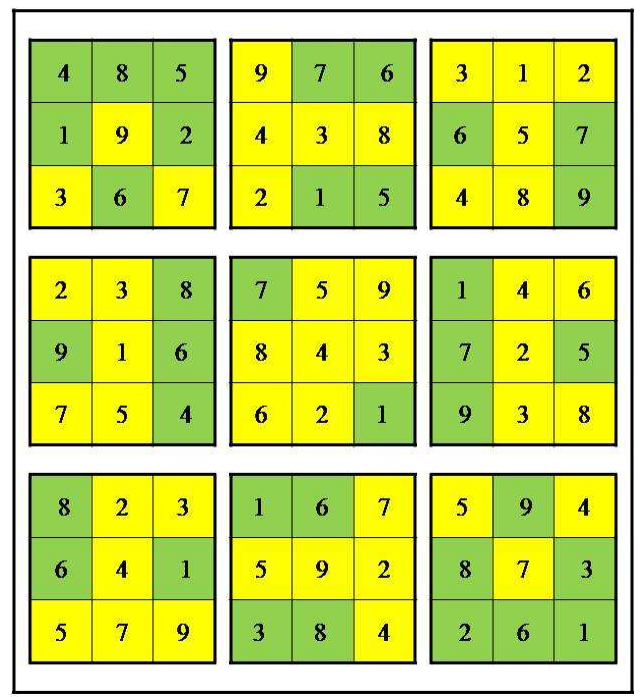

(j)

Gambar 10(a) - (j). Proses pencarian solusi Su Doku

\section{KESIMPULAN}

Berdasarkan penelitian yang telah dilakukan oleh penulis, dsapat diperoleh beberapa kesimpulan, diantaranya :

1. Telah dihasilkan sebuah aplikasi $S u$ Doku Solver, implementasi dari metode backtracking algorithm untuk menampilkan solusi Su Doku pola $9 \times 9$ yang unik dan terbukti bahwa teori metode backtracking algorithm dalam penggunaan pencarian solusi $S u$ Doku pola 9x9 cukup tepat.

2. Aplikasi Su Doku Solver ini memiliki fungsi sebagai penyedia solusi bagi permasalahan pencarian angka-angka yang valid didalam pengisian sebuah matriks Su Doku. Setelah memilih level Su Doku, user bisa langsung melihat tampilan solusinya ketika mengeksekusi perintah pencarian solusi $\mathrm{Su}$ Doku.

3. Metode umum pencarian solusi $S u$ Doku adalah dengan kombinasi teknik pemindaian (scanning), penandaan (marking), dan analisis (analyzing).

a. Pemindaian, berupa proses memindai baris atau kolom untuk mengindentifikasi baris mana dalam suatu grid yang terdapat angka-angka tertentu yang selanjutnya disebut angka awal. Proses ini kemudian diulang pada setiap kolom (atau baris) secara sistematis. Kemudian menentukan nilai dari suatu sel dengan membuang nilainilai yang tidak mungkin.

b. Penandaan, berupa analisa logika dengan menandai kandidat angka yang dapat dimasukkan dalam sebuah sel.

c. Analisis, berupa eliminasi kandidat, dimana kemajuan dicapai dengan mengeliminasi kandidat angka secara berturut-turut hingga sebuah sel hanya punya 1 kandidat.

4. Pencarian solusi Su Doku pada aplikasi $S u$ Doku Solver dilakukan menggunakan backtracking algorithm/algoritma runut balik, 
dimana pencarian dilakukan dari sel sisi kiri atas menuju sel sisi kanan bawah matriks, dengan rincian pencarian pada baris dimulai dari kiri ke kanan dan pada kolom dimulai dari atas kebawah. Pada implementasinya algoritma akan mengumpulkan semua angka kemungkinan yang akan menjadi solusi, kemudian menandai angka tersebut dan meletakkannya di dalam matriks Su Doku. Setelah itu algoritma akan memulai proses pencarian solusi pada sel pertama (sel kiri atas), jika sel pertama merupakan angka awal, maka pencarian dilakukan pada sel setelahnya, begitu seterusnya. Pada proses pencarian algoritma mengecek apakah angka yang ditandai tersebut memiliki kesamaan pada satu baris, kolom, dan grid. Apabila terdapat angka yang sama pada sel kedua, ketiga, dan seterusnya, algoritma akan melakukan backtracking/runut balik ke sel sebelumnya dan angka yang sama tersebut diganti dengan angka yang baru. Pengecekan terus dilakukan sehingga semua sel pada matriks Su Doku telah terisi semua dengan tidak ada kesamaan angka pada satu baris, kolom, dan grid.

5. Metode pencarian menggunakan backtracking algorithm mampu memberikan solusi Su Doku yang unik, yakni semua sel terisi masingmasing dengan angka 1 sampai dengan 9, dengan syarat tidak boleh ada angka yang sama pada satu baris, kolom, dan grid.

\section{DAFTAR PUSTAKA}

[1] Arifiyanto, W. A.. 2007. Penggunaan Algoritma Backtracking Dalam Penyelesaian Permainan S Sudoku. Makalah STMIK 2007096. Bandung : Teknik Informatika Institut Teknologi Bandung.

[2] Desiani, A. dan Arhami, M.. 2006. Konsep Kecerdasan Buatan. Yogyakarta : Penerbit Andi.

[3] Morenvino, M., Ray, A. I., Anton, R. S.. 2006. Penerapan Algoritma Runut-Balik Untuk Penyelesaian Teka-Teki Sudoku. Makalah STMIK 2006-046. Bandung : Teknik Informatika Institut Teknologi Bandung.

[4] Musadik, R. 2010. Pengantar dan Sejarah Sudoku. Diakses 22 Maret 2011. http://universologi.blogspot.com/2010/03/per mainan-seperti-sudoku-sudah-dikenal.html. 